\title{
MODEL LATIHAN JATUHAN PADA ATLET JUDO UNTUK PEMULA
}

\author{
NU'MAN AJI HAQQO \\ SDN 1 Sumberbandung Kec. Pagelaran Utara \\ Surel : ajihaqqo58@gmail.com
}

\begin{abstract}
Objectives of research and development Develop and implement the fall training model on Judo Athlete for Beginners, the results of the development of the fall training model on Judo Athlete for Beginners, In addition, research and development is conducted to obtain in-depth information about the development and implementation of the exercise model and know the effectiveness, Model created. This research and development uses Research \& Development (R \& D) development methods from Borg and Gall. Subjects in this research and development are reserved for Beginner judo athletes.

The model effectiveness test uses a drop test instrument to collect data on Judo's fall ability. Analysis of research data using t test with significance level of 0.05. Data analysis obtained the average data value of 4 models of fall training on judo athletes for beginners is feasible and effective to improve the fall in the beginner athlete. In the significance test the difference from the data of 4 techniques that the difference from pre test and post rear fall test from stand (1) Test $0.00<0.05$. (2) Front fall test from standing: $0.00<0.05$ (3) Fall test falls forward: $0.01<0.05$ (4) Left-left fall test:0.00<0.05 indicates that there is a significant difference between before and after the effect of treatment Model of fall training on judo athletes for beginners and can increase the fall of judo athletes.
\end{abstract}

Keywords: model, technique, fall and judo

\section{PENDAHULUAN}

Latihan merupakan suatu proses yang sistematik untuk meningkatkan kualitas fisik dan bertujuan untuk meningkatkan penampilan olahraga dimana seorang atlet dipersiapkan untuk performa tertinggi. Untuk itu model latihan menjadi sengat penting bagi seorang pelatih. Latihan menjadi sangat efektif jika dilakukan dengan program yang baik. Kondisi fisik adalah satu kesatuan utuh dari komponenkomponen yang tidak dapat dipisahkan begitu saja. Dalam mengembangkan kondisi fisik dan kebugaran jasmani yang perlu diperhatikan dan dikembangkan adalah daya tahan (endurance), kekuatan (strength), kelentukan (flexibility), daya ledak otot (power), kecepatan (speed), kelincahan (balance).

Judo adalah salah satu cabang olahraga bela diri yang berasal 


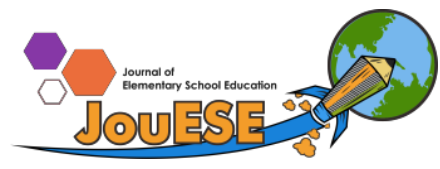

dari Jepang dan telah populer dewasa ini. Olahraga Judo diciptakan oleh Prof. Jigoro Kano atau Maha Guru Jigoro Kano Pada 1882. ${ }^{1}$ Judo dikembangkan dari seni bela diri kuno Jepang yang disebut Jujutsu. Pemain judo disebut judoka atau pejudo. Tekhnik Judo tidak sesederhana seperti apa yang terlihat yaitu, bertarung, membanting, dan menjatuhkan lawan saja. Tetapi Pejudo harus dapat melakukan gerakan Judo sesuai tekhnik yang benar.

\section{Model Latihan}

Latihan dapat didefinisikan sebagai peran serta yang sistematis dan bertujuan untuk meningkatkan kapasitas fungsional fisik dan daya tahan latihan. Dalam bidang olahraga tujuan akhir latihan adalah untuk meningkatkan penampilan olahraga. Tujuan latihan adalah mengaktifkan peralatan genetik sebuah sel, sehingga mampu memproduksi lebih banyak protein. Jadi melalui latihan sifat hakiki sebuah sel tidak mengalami perubahan, yang meningkat adalah kegunaan atau fungsi sebuah sel jadi lebih besar melalui latihan yang menjadikan kemampuan berprestasi seseorang menjadi lebih besar.

Proses latihan terdapat pembangunan fisik multilateral yang merupakan latihan dasar untuk sukses dalam semua cabang olahraga termasuk Futsal. Menurut James (2012: 42) Latihan adalah suatu proses yang sistematis dan berlatih yang dilakukan secara berulang ulang dengan kian hari kian menambah jumlah beban latihan serta intensitas latihannya. Pemula yang mengembangkan dasar latihan yang kuat akan dapat mentoleransi lebih baik kegiatan-kegiatan latihan olahraga spesifik dan pada akhrinya memiliki potensi yang lebih besar untuk pengembangan olahraga kecabangan. Bompa (2015:12) mengatakan bahwa latihan merupakan suatu kegiatan olahraga yang sistematis dalam waktu yang panjang, ditingkatkan secara bertahap dan perorangan, bertujuan membentuk manusia yang berfungsi fisiologis dan psikologisnya untuk memenuhi tuntutan tugas. Pengertian tersebut dapat didefinisikan latihan merupakan proses yang sistematis dari berlatih atau bekerja, yang dilakukan secara berulang-ulang, dengan 
kian hari kian menambah jumlah beban latihan atau pekerjaannya. Seseorang perlu belajar teknik serta menekankan pada persiapan taktik dan mental yang lebih matang sehingga prestasi dalam cabang olahraga yang diikuti dapat lebih unggul dibandingkan atlet lainnya.

Menurut pendapat para ahli di atas, disimpulkan bahwa model latihan adalah bentuk suatu kegiatan yang dilakukan secara berulangulang dan terprogram, dimana setiap pengulangan harus bertambah frekuensinya, agar terjadi peningkatan dalam latihannya.

\section{METODE PENELITIAN}

Penelitian dan pengembangan dalam model latihan ini menggunakan pendekatan kualitatif dan kuantitatif serta menggunakan model pengembangan Research \& Development $(R \& D)$ dari Borg dan Gall yang terdiri dari sepuluh langkah pada gambar di bawah ini.

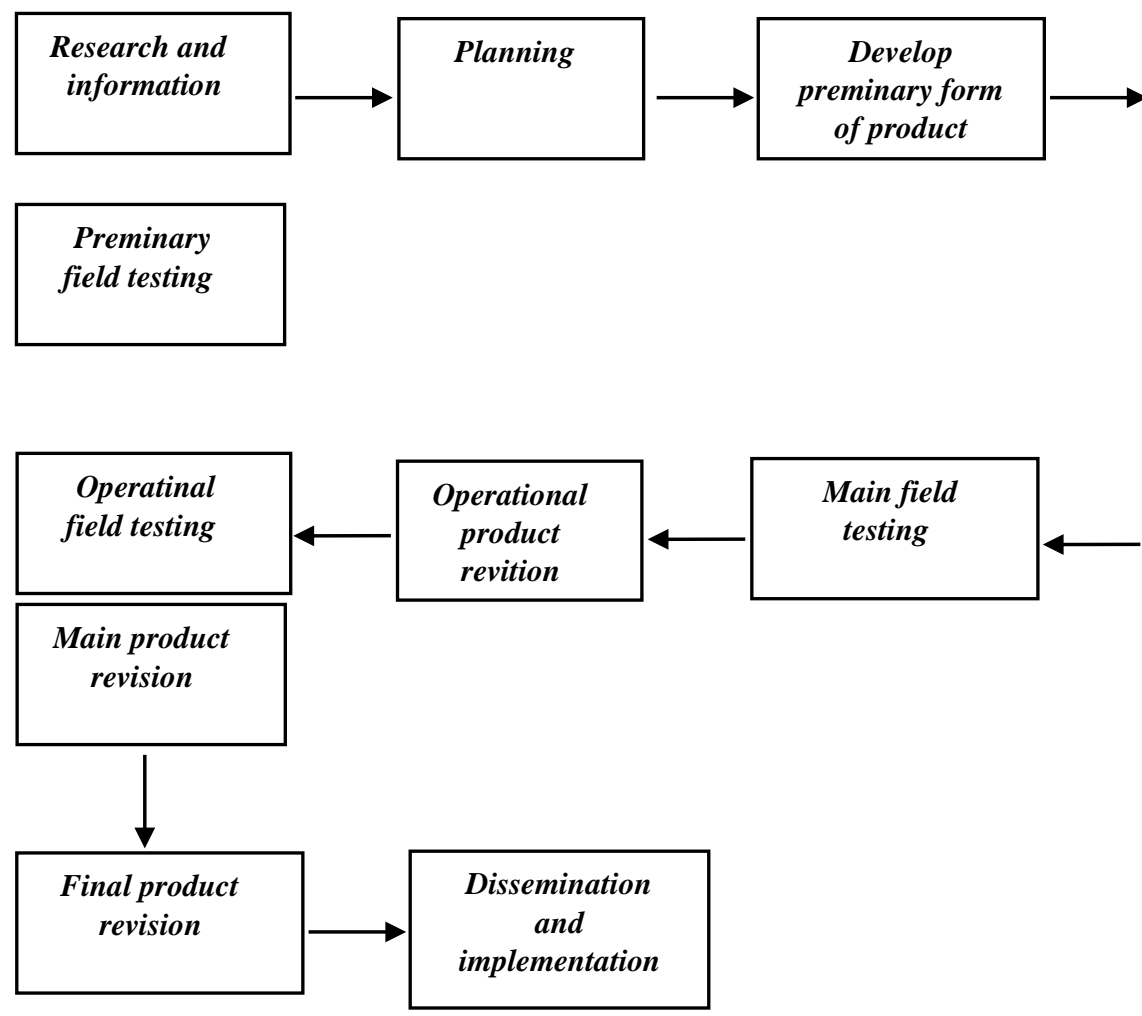

Gambar 1. Instructional Design $R$ and $D$ Sumber: Walter R. Borg and Meredith D. Gall, Educational Research: An Introduction, $4^{\text {th }}$ Edition. (New York: Longman Inc., 1983) 


\section{HASIL DAN PEMBAHASAN}

\section{Hasil Uji Coba Kelompok Kecil}

Pengembangan model latihan futsal yang peneliti buat setelah dievaluasi ahli, berdasarkan evaluasi ujicoba kelompok kecil dengan 15. Berdasarkan evaluasi uji coba kelompok kecil yang dilakukan oleh peneliti dapat disimpulkan sebagai berikut:

a. Seluruh variasi model latihan jatuhan pada atlet judo untuk pemula dapat dilakukan oleh atlet judo pemula, yang perlu diperhatikan adalah model latihan dimulai dari tingkatan mudah sampai sulit agar kemampuan jatuhan pejudo pemula meningkat.

b. Perlu adanya contoh gerakan terlebih dahulu pada tiap model latihan supaya mudah untuk memahami rangkaian gerakan.

c. Pada saat diterapkan model latihan di lapangan atlet kurang memperhatikan jadi tugas pelatih harus sering memantau agar tujuan latihan dan target latihan tercapai.

\section{Hasil Uji Coba Kelompok Besar}

Setelah terdapat hasil pengembangan produk latihan jatuhan pada atlet judo untuk pemula ini diujicobakan dalam skala kecil dan telah direvisi, maka tahap selanjutnya adalah melakukan ujicoba kelompok besar. Berdasarkan hasil uji coba kelompok kecil yang telah dievaluasi oleh para ahli, kemudian peneliti melakukan revisi produk awal dan memperoleh 33 model latihan jatuhan pada atlet judo untuk pemula yang akan digunakan dalam uji coba kelompok besar. Langkah selanjutnya setelah model mengalami revisi tahap kedua oleh para ahli maka di lanjutkan dengan menguji cobakan produk kepada kelompok besar dengan menggunakan subjek penelitian 60 pejudo pemula terdiri dari 3 klub, Klub judo Metro Lampung,Klub judo junior Metro Lampung Klub Judo Kelapa Gading Jakarta, . 


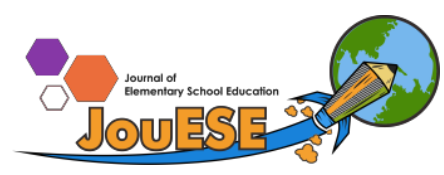

\section{Hasil Uji Efektivitas}

Langkah selanjutnya setelah model mengalami revisi tahap dua dari ahli dan uji coba kelompok kecil dan kelompok besar maka dilanjutkan dengan menguji cobakan produk dengan menggunakan subyek penelitian sebanyak 50 subjek penelitian. Pemberian treatment dilaksanakan dalam kurun waktu 1 bulan, 1 minggu dimulai dari bulan April sampai dengan Mei 2017 dengan jumlah 16 kali pertemuan, senin, rabu jum'at 3 kali dalam seminggu Selama penelitian dilaksanakan kelompok treatment diberikan 33 model latihan jatuhan, setiap kali pertemuan. Sebelum pemberian treatment subjek penelitian di tes awal dengan menggunakan instrument tes penilaian masing masing tekhnik jatuhan yaitu jatuh belakang dari berdiri, jatuh samping kanan-kiri dari berdiri, jatuh menggelinding ke depan (zempo kaiten), jatuh ke depan dari posisi berdiri, dalam tekhnik jatuhan judo pada subjek penelitian sebelum dan sesudah perlakuan.

Hasil test sebelum dan sesudah diberikan perlakuan dapat di simpulkan bahwa model latihan jatuhan pada atlet judo untuk pemula layak dan efektif untuk meningkatkan jatuhan pada atlet pemula. Dalam uji signifikasi perbedaan dengan SPSS 21 didapat dari data 4 teknik bahwa selisih dari pre test dan post tes jatuhan belakang dari berdiri (1) Tes $0.00<$

0.05 . (2) Tes jatuhan depan dari berdiri : $0.00<0.05$ (3) Tes jatuhan mengelinding ke depan : $0.01<0.05$ (4) Tes jatuhan kesamping kanan-kiri :

$0.00<0.05$ menunjukan berarti terdapat perbedaan yang signifikasi antara sebelum dan sesudah adanya pengaruh perlakuan model latihan jatuhan pada atlet judo untuk pemula

Berdasarkan hasil penelitian dapat disimpulkan bahwa model latihan jatuhan pada atlet judo untuk pemula memiliki efektivitas yang signifikan. 


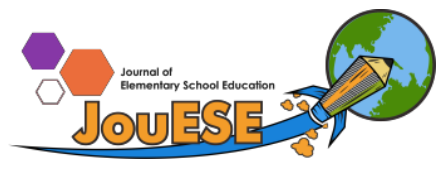

\section{Pembahasan Produk}

Produk ini setelah dikaji mengenai beberapa kelemahan yang perlu pembenahan, maka dapat disampaikan beberapa keunggulan produk ini antara lain:

a. Dapat meningkatkan jatuhan pada atlet pemula.

b. Model latihan jatuhan NAH pada atlet judo lebih efektif dan efisien. Model yang digunakan sangat bervariatif yang dapat meningkatkan tingkat antusias atlet dalam latihan.

c. Atlet Pemula dapat merasakan kenyamanan dan keamanan dalam proses latihan judo.

d. Model ini dapat menjadi Turbo booster motivation anak untuk fisik khususnya teknik jatuhan atlet judo atlet pemula.

e. Sebagai referensi latihan di Club.

f. Dapat membantu pelatih dalam melatih dan mencari atlet pemula.

g. Sumbangan bagi ilmu pengetahuan khususnya kepelatihan seluruh di Indonesia.

\section{Keterbatasan Produk}

Penelitian R n D atau Research n Development ini di buat sesempurna mungkin sesuai kemampuan dari penenliti, namun apabila dalam penelitian ini masih terdapat banyak keterbatasan yang harus diakui dan dikemukakan sebagai bahan untuk pertimbangan dalam menggeneralisir hasil dari penelitian yang dicapai.

Adapun keterbatasan-keterbatasan tersebut antara lain sebagai berikut :

a. Saat peneliti melakukan uji coba lapangan baikknya di lakukan pada cakupan ruang lingkup yang lebih lama

b. Produk yang dibuat jauh dari kata sempurna

c. Sarana dan Prasarana kurang memadai dan terbatas

d. Penjelasan dalam gambar latihan keterampilan kurang sempurna 


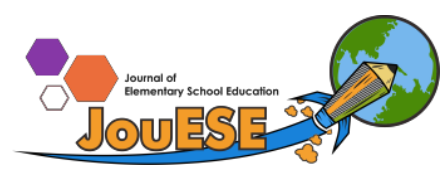

\section{SIMPULAN}

Model latihan jatuhan pada atlet judo untuk pemula diciptakan oleh peneliti untuk membantu pelatih atau guru dalam memvariasi latihan keterampilan, meningkatkan keterampilan jatuhan atlet judo untuk pemula sebgaai referensi latihan. Model ini dibuat atas dasar kebutuhan anak khususnya dalam atlet pemula.

Berdasarkan data yang diperoleh, hasil uji coba lapangan dan pembahasan hasil penelitian :

1. Dengan anak bisa berlatih dengan efektif dan efesien

2. Dengan Model Latihan jatuhan pada atlet judo untuk pemula bisa meningkatkan gairah dalam berlatih aspek fisik dan keterampilan.

\section{DAFTAR PUSTAKA}

Borg, Walter R. \& Meredith D. Gall, Fouth Edition Research An Introduction. USA: Logman, 1983.

Irawan, A. (2009) Teknik dasar modern futsal. Jakarta: Pena

Pundi Askara. James W Lennox . el.at ., Soccer skills \& drills

(National Soccer Coaches

Association of America :Human Kinetics. 2006) h. 152

John D. Tenang Mahir Bermain Futsal. Bandung: Mizan Media

Utama, 2008. John P Buckley and Adrienne R Hughes. Exercise

Physiology in Special

Populations, (Elsevier Limited. All rights reserved ;2008) h.12

Sugiyono, Metode Penelitian Kuantitatif, Kualitatif dan $R \& D$. Bandung: Alfabeta, 2013.

Sukmadinata, Metode Penelitian Pendidikan. Jakarta: PPs UPI dan PT Remaja Rosdakarya, 2005.

Tangkudung, James. dan Wahyuningtyas Puspito Rini, Kepelatihan Olahraga "Pembinaan Prestasi Olahraga” Jakarta: Cerdas Jaya, 2012. 
Vol. 1, No. 2, 2021

Widiastuti. Tes dan Pengukuran Olahraga. Jakarta: PT. Bumi Jaya, 2011. 